\title{
Bør nyfødte screenes med pulsoksymetri?
}

\author{
Medfødt hjertefeil kan oppdages tidligere ved hjelp av pulsoksymetri.
}

Medfødt hjertefeil kan oppdages ved ultralydundersøkelse i svangerskapet eller ved klinisk undersøkelse like etter fødselen, men slike undersøkelser fanger ikke opp alle tilfellene. Noen spedbarn med medfødte hjertefeil blir kritisk dårlige når ductus lukker seg etter utskrivning fra sykehus. Tidlig diagnostikk og behandling av alvorlig hjertefeil kan bedre prognosen. Derfor er det ønskelig

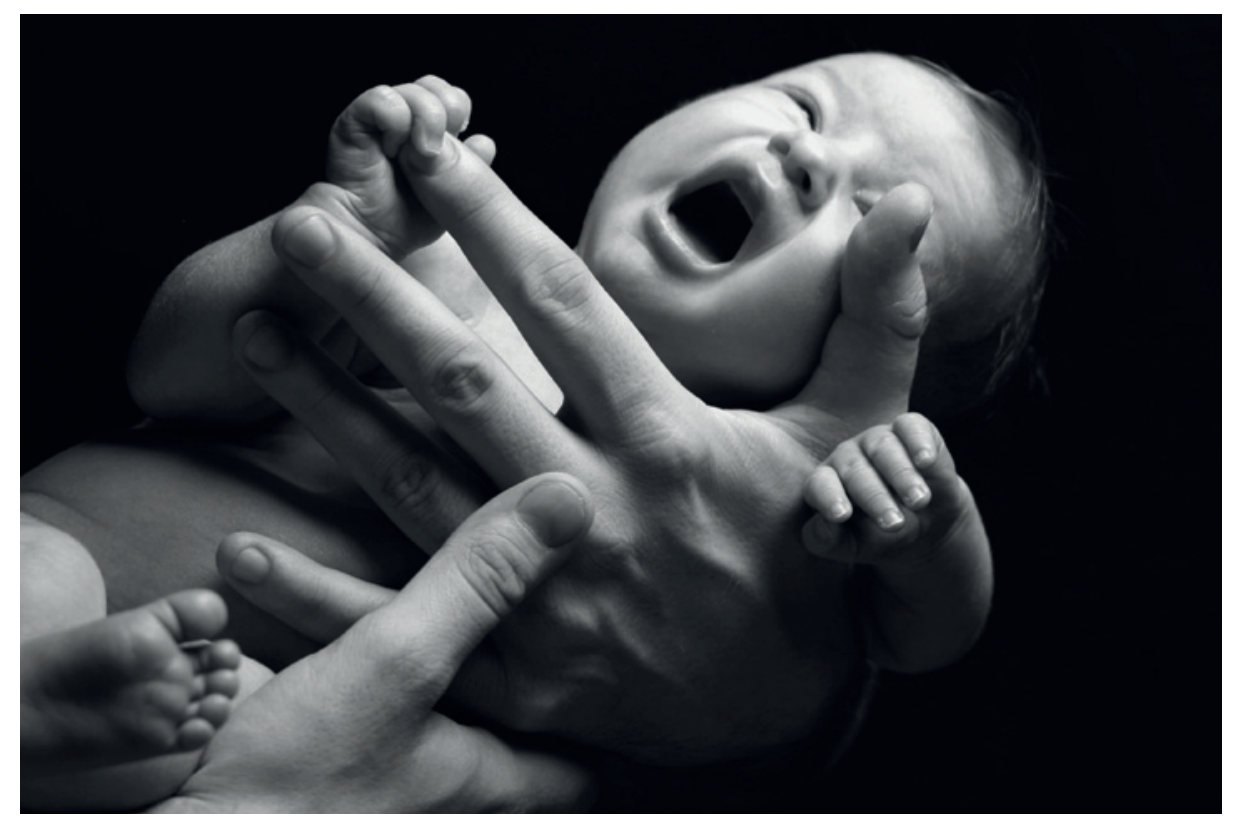

Illustrasjonsfoto Istockphoto

\section{Mange ble syke etter 11. september 2001}

\section{Mange av redningsarbeiderne ved World Trade Center i New York fikk fysiske og psykiske helseplager etter terrorhendelsene.}

Mer enn 50000 personer deltok i redningsog gjenopprettingsarbeidet etter angrepene på World Trade Center i New York 11. september 2001. Redningsarbeiderne ble eksponert for bl.a. luftbårne giftstoffer, pulveriserte bygningsmaterialer og psykisk stress, og det er tidligere påvist at de har økt forekomst av flere helseplager. I en ny studie beskrives fysiske og psykiske plager hos redningsarbeiderne gjennom de siste ni årene (1).

I studien inngikk 27449 politimenn, bygningsarbeidere og kommunalt ansatte som med bedre screeningmetoder. I en engelsk studie har man nylig undersøkt nytten av pulsoksymetri som screening for hjertefeil hos nyfødte (1).

Av totalt 20055 nyfødte barn hadde 53 større medfødte hjertefeil (hvorav 24 kritisk syke), tilsvarende en prevalens på 2,6 per 1000 levendefødte. Sensitiviteten til pulsoksymetri for å oppdage kritisk hjertefeil var

$75 \%$ (95\% KI 53-90\%) og for å oppdage alle større hjertefeil 49\% (KI 35-63\%). Etter eksklusjon av nyfødte der hjertefeil allerede var mistenkt etter ultralydunders $\varnothing-$ kelse i svangerskapet, falt sensitiviteten til henholdsvis $58 \%$ og $29 \%$. Falskt positive funn ble notert hos 169 nyfødte $(0,8 \%)$, hvorav 40 hadde annen sykdom som krevde rask behandling. Spesifisiteten var 99,2\%. De alvorligste hjertefeil som pulsoksymetri ikke fanget opp, var kritisk tranghet $i$ aortabuen.

- Denne studien føyer seg til mange andre om pulsoksymetriscreening hos nyfødte. Selv om flere store studier viser sannsynlig nytte av dette, er det fortsatt usikkert hvordan slik screening påvirker morbiditet, mortalitet og kostnader. Derfor må screening følges opp med langtidsstudier, sier overlege Gunnar Norgård ved Barnehjerteseksjonen, Oslo universitetssykehus, Rikshospitalet.

\section{Erlend T. Aasheim}

erlend.aasheim@legeforeningen.no

Tidsskriftet

\section{Litteratur}

1. Ewer AK Middleton LJ, Furmston AT et al. Pulse oximetry screening for congenital heart defects in newborn infants (Pulse0x): a test accuracy study. Lancet 2011; 378: 785-94.

deltok i rednings- og gjenopprettingsarbeidet. Astma, sinusitt og gastroøsofageal reflukssykdom forekom hos henholdsvis $27,6 \%$, $42,3 \%$ og 39,3\% i løpet av oppfølgingsperioden. Depresjon, posttraumatisk stressyndrom og panikkangst forekom hos henholdsvis $7,0 \%, 9,3 \%$ og $8,4 \%$ av politimennene og hos $27,5 \%, 31,9 \%$ og $21,2 \%$ av de øvrige studiedeltakerne. Forfatterne konkluderte med at en betydelig andel av redningsarbeiderne fortsatt hadde fysiske og mentale helseplager ni år etter terrorhendelsene.

- For de fleste tilstandene var det en doserespons-sammenheng mellom eksponering for støv og røyk på hendelsesstedet og senere utvikling av sykdom, sier overlege Håkon Lasse Leira ved Arbeidsmedisinsk avdeling, St. Olavs hospital. - Ett problem med studien er at man ikke har god kontroll på hvem som ble inkludert og hvem som ikke ble det. Dessuten var deltakelse i studien frivillig, slik at funnene ikke nødvendigvis er representative for alle som bidro i redningsarbeidet. Videre er alle sykdommer som oppsto i oppfølgingsperioden tatt med, også sykdom som har andre årsaker. Men studien viser uansett at det er viktig med langvarig oppfølging av helseeffekter etter store katastrofer, sier Leira.

\section{Erlend T. Aasheim}

erlend.aasheim@legeforeningen.no

Tidsskriftet

\section{Litteratur}

1. Wisnivesky JP, Teitelbsum SL, Todd AC et al. Persistence of multiple illnesses in World Trade Center rescue and recovery workers: a cohort study. Lancet 2011; 378: 888-97. 